\title{
Influence of Farmers Human Resources Quality and Group Conditions on Simantri Application Level in Bali
}

\author{
I Gusti Agus Maha Putra Sanjaya ${ }^{1}$, Nyoman Suparta ${ }^{2}$ \\ ${ }^{I}$ Animal Husbandry Department, Agriculture Faculty, Warmadewa University, Bali-Indonesia \\ ${ }^{2}$ Animal Husbandry Faculty, Udayana University, Bali-Indonesia
}

\begin{abstract}
Simantri is a regional government program started in 2009 which is one of the solutions to overcome the limitation of agricultural land as a result of land conversion and to improvement the farmer's income in Bali. The aims of this research were to analyze the condition of Simantri application level in Bali, and also the influence of farmers human resources quality and the Simantri group condition on the application of cattle breeding, food crops, and cattle waste processing. Structured questionnaires were used to obtain information from 138 respondents consisting of chairmen, secretaries, and treasurers of forty-six groups of Simantri from 2009-2010. The groups of Simantri selected by purposive sampling method. Data obtained were analyzed by a descriptive method and statistic analysis. Results indicated that on average the Simantri application level classified very high. When viewed from three types of main Simantri activities, it turns out the application level of cattle waste processing on average is classified as moderate. The farmer's human resources quality have proved has a positive and significant impact on the application of cattle breeding, food crops, and cattle waste processing. The Simantri group condition statistically has the positive but not significant effect on the application of cattle breeding, food crops, and cattle waste processing.
\end{abstract}

Keywords: Application Level, Integrated Farming System, Simantri,

Author Correspondence:

I Gusti Agus Maha Putra Sanjaya

Animal Husbandry Department, Agriculture Faculty, Warmadewa University, Bali-Indonesia

Phone: 081246431208 E-mail: iga.sanjaya@gmail.com

\section{Introduction}

\subsection{Background of the Study}

The problem facing the world today is the increasing number of people that are not counterbalanced by the increasing amount of food available to sufficient the human life needs. Human life can not be separated from food. Food sources not only come from crops but are also sourced from livestock. Conversion of agricultural land to non-agricultural land has exacerbated the carrying capacity of land to provide food for human needs. In Indonesia, since the increasing demand for land for industry and housing has led to a decline of productive agricultural lands. The same thing happened in Bali, with the total area of Bali Province about 5,634.40 hectares where the current agricultural land area is about 81 hectares. This number decreased drastically compared to 2000 which is about 110 hectares, before the large-scale land conversion for housing and the tourism industry. [1] said that less intensive of agriculture in rice fields will lead to the conversion of agricultural land. On the other side, the limitations of capital, less of agribusiness insight, as well as traditional maintenance management are the causes of low productivity and diversification of farming [2].

One of a solution to overcome the imbalance between the existing land area with the food requirement is to the application an agricultural system that integrates crops with livestock. Integrated 
farming between crops and livestock have long been practiced by farmers in Indonesia, as well as in Bali. This farming system is a solution of dependence on external input because of its complementary nature. The purpose of farming system application in a single farming household business is to reduce the risk of crop failure and maximize revenue.

Another reason farmers conducts mixed farming is the habit (tradition), to maximize revenues from limited resources, and to increase the benefits of linkage and sustainability among business branches. The sustainability of agricultural business will be achieved when considering the effectiveness and efficiency of resource use in the production process. There are three main functions of the crop-livestock integration model: (a) improving people's welfare and push the economic growth, (b) strengthening local food security, and (c) maintaining environmental sustainability [3].

The integration of crops with cattle is an integrated application of farming through the concept of low external input. This system is very profitable, because cattle beside cattle waste processed into organic fertilizer to improve soil fertility, can also use grass and forage feed that grows wild, straw or agricultural waste as cattle feed. This system can also increase farmers income by cattle waste processing into compost. Compost can then be sold to other farmers or people who need it. The croplivestock integration system has been proven to increase farmer income [4],[5],[6].

To resolve the problem of land conversion as well as to increase the farmer's income in Bali, the Bali Regional Government began in 2009 adopt Prima Tani model as an effort to achieve the vision in agriculture. The adoption of Prima Tani model in integrated farming system (Simantri) was followed up with memorandum of understanding $(\mathrm{MoU})$ between Agricultural Research and Development Institution and Bali Regional Government No: 075/12 / KB / B.PEM / 2009 and No: 680 / HM.240 / I.10 / 09 on 28 October 2009 with the follow-up of the development of an integrated farming model sustainably. To increase the District Government support followed up by the MoU between the governor and the regent of Bali, so it is expected to synergize in agricultural development in Bali [7].

The purpose and objectives of Simantri's programme are: (1) supporting the development of diversification of agricultural business in an integrated and agribusiness concept; (2) as one of the efforts to reducing poverty and unemployment, supporting the development of environmentally friendly, clean and green Bali and Bali Organic programme to "Bali Mandara"; (3) integrate crops and livestock with completeness: compost processing unit, feed processor, bio urine installation and biogas; (4) implemented gradually and sustainably with the target of increasing the farmers income, at least doubled in the next 4-5 years.

The Simantri application level by farmers will be good if, this programme is really needed by farmers in Bali to solve their problems. Besides of innovation ability, the innovation application level by farmers will be influenced also by the attitude of themselves. The attitude of farmers to a technological innovation is influenced by the internal factors (individual personality characteristics) and external factors (factors outside the individual self) [8]. Furthermore, external factors such as norms, habits, social communication, social interaction, and social learning of individual farmers in a social system are more dominant in influencing farmers attitude and the decision to innovation. The facts show that there are still many problems in the application of this programme. There is an imbalance between the purpose and objectives of Simantri programme with the current condition of the Simantri group. Therefore, it is interesting to analyze more about the application of Simantri programme by farmers who participate in this programme. 


\subsection{The problem of the Study}

How is the current condition of Simantri application level in Bali? How is the influence of farmers human resources quality and the Simantri group condition on the application of cattle breeding, food crops, and cattle waste processing?

\subsection{The objective of the Study}

The aims of this study were to analyze the condition of Simantri application level in Bali, and also the influence of farmers human resources quality and the Simantri group condition on the application of cattle breeding, food crops, and cattle waste processing.

\subsection{Hypothesis}

Simantri application level by farmers who participate in this programme is good. The farmer's human resources quality and the Simantri group condition are influences on the application of cattle breeding, food crops, and cattle waste processing.

\section{Material and Methods}

\section{Research Design}

This research is a survey research designed as explanatory research design because it intends to explain the relationship between independent variables and dependent variables. In addition to analyzing the Simantri application level by farmers who participating in this programme, this research also analyzed the effect of farmers human resources quality (X1) and the Simantri group condition (X2) on the application of cattle breeding (X3), food crops (X4), and cattle waste processing (X5). X1 consists of 7 indicators (age, formal education, non formal education, Simantri knowledge, attitude about Simantri, skill about Simantri, and experience), X2 consists of 3 indicators (residence distance, local culture, social interaction), X3 composed from 6 indicators (use of a quality calves, provide of cages, provide and feeding, maintenance, disease control, reproduction understanding concept), X4 consists of 2 indicators (food crops, crops waste), X5 consists of 3 indicators (biogas, compost, biourine)

\section{Location and Time of the Study}

The research was conducted in eight regencies and one city of Bali. There are 16 groups of Simantri in Buleleng regency, 3 groups in Jembrana, Tabanan, Badung and Gianyar, 2 groups in Klungkung, 7 groups in Bangli, 8 groups in Karangasem, and 1 group in Denpasar which lasted for 3 months. The groups of Simantri were determined by purposive sampling method.

\section{Population and Sample}

The target population in this research is the Simantri group who have followed the Simantri programme for at least two years. The type of unit of analysis in this study is the group, which became the sample in this study is the entire population of groups who follow Simantri from 2009-2010 which amounted to 46 groups, whose members are work as farmers. Total respondents were 138 consisted of chairmen, secretaries, and treasurers of forty-six groups of Simantri from 2009-2010. Census method is the method used for sampling because the number of respondents is not too much and in order to obtain more accurate research results.

\section{Sources and Data Collection Techniques}


Influence of Farmers Human Resources Quality and Group Conditions on Simantri Application Level in Bali

Source of data consisted of primary and secondary data. The qualitative and quantitative data were collected directly and followed by an in-depth interview, observation, and documentation.

\section{Research Variable}

The variables observed in this research are the farmer's human resources quality as internal factors and the Simantri group condition as an external factor on the application of cattle breeding, food crops, and cattle waste processing.

\section{Data analysis}

Data were analyzed statistically and by a descriptive method. Descriptive method was used for interpretation the Simantri application level by farmers who participate in this programme, meanwhile statistical analysis was used to analyse the influence of farmers human resources quality and the Simantri group condition on the application of cattle breeding, food crops, and cattle waste processing by PLS (partial least square) with Smart PLS software version 2.0. Determination of the Simantri application level by farmers who participate in this programme were measured based on the scores achieved by respondents using the formula "interval class" that is dividing the difference between the highest and lowest values with the number of categories [9]. The total score of the variable is based on the number of questions in the questionnaire (not in percentage), meanwhile, the proportion or average score of the score is the total score divided by the number of questions [10].

\section{Results and Discussion}

\subsection{Simantri Application Level in Bali}

Application of Simantri by respondents in this research is divided into three: the application of cattle breeding, food crops, and cattle waste processing. Based on the research result, Simantri application by the respondents can be seen in Table 1 below.

Table 1.

Distribution of Respondents Based on Simantri Application

\begin{tabular}{|c|c|c|c|c|c|}
\hline No & Variable & $\begin{array}{l}\text { Attainment } \\
\text { Score }\end{array}$ & $\begin{array}{l}\text { Variable } \\
\text { Category }\end{array}$ & $\begin{array}{c}\text { No of } \\
\text { Respondent }\end{array}$ & $\begin{array}{c}\text { Percentag } \\
\text { e (\%) }\end{array}$ \\
\hline \multirow{6}{*}{1} & \multirow{5}{*}{ Simantri Application } & $>4.2-5$ & Very High & 90 & 65.22 \\
\hline & & $>3.4-4.2$ & High & 45 & 32.60 \\
\hline & & $>2.6-3.4$ & Moderate & 3 & 2.18 \\
\hline & & $>1.8-2.6$ & Low & 0 & 0 \\
\hline & & $1-1.8$ & Very Low & 0 & 0 \\
\hline & & Total & & 138 & 100 \\
\hline \multirow{6}{*}{2} & \multirow{5}{*}{$\begin{array}{l}\text { The Application of The } \\
\text { Cattle Breeding }\end{array}$} & $>4.2-5$ & Very High & 120 & 86.95 \\
\hline & & $>3.4-4.2$ & High & 18 & 13.05 \\
\hline & & $>2.6-3.4$ & Moderate & 0 & 0 \\
\hline & & $>1.8-2.6$ & Low & 0 & 0 \\
\hline & & $1-1.8$ & Very Low & 0 & 0 \\
\hline & & Total & & 138 & 100 \\
\hline \multirow{6}{*}{3} & \multirow{5}{*}{$\begin{array}{c}\text { The Application of The } \\
\text { Food Crops }\end{array}$} & $>4.2-5$ & Very High & 138 & 100 \\
\hline & & $>3.4-4.2$ & High & 0 & 0 \\
\hline & & $>2.6-3.4$ & Moderate & 0 & 0 \\
\hline & & $>1.8-2.6$ & Low & 0 & 0 \\
\hline & & $1-1.8$ & Very Low & 0 & 0 \\
\hline & & Total & & 138 & 100 \\
\hline
\end{tabular}


Influence of Farmers Human Resources Quality and Group Conditions on Simantri Application Level in Bali

\begin{tabular}{|c|c|c|c|c|c|}
\hline 4 & $\begin{array}{l}\text { The Application of The } \\
\text { Cattle Waste Processing }\end{array}$ & $\begin{array}{r}>4.2-5 \\
>3.4-4.2 \\
>2.6-3.4 \\
>1.8-2.6 \\
1-1.8\end{array}$ & $\begin{array}{l}\text { Very High } \\
\text { High } \\
\text { Moderate } \\
\text { Low } \\
\text { Very Low }\end{array}$ & $\begin{array}{c}21 \\
51 \\
45 \\
6 \\
15\end{array}$ & $\begin{array}{c}15.22 \\
36.96 \\
32.60 \\
4.36 \\
10.86\end{array}$ \\
\hline & & Total & & 138 & 100 \\
\hline
\end{tabular}

Base on the research results, most respondents $(65.22 \%)$ have a very high level of Simantri application with average attainment score 4.325. From the point of view of the application of the three types of main Simantri activities shows that most of the respondents have very high application level on the cattle breeding, food crops, and high application level on cattle waste processing with average each attainment score are 4.625, 4.746 and 3.135.

\subsection{Direct Effect Testing}

The test of the influence of farmers human resources quality and the Simantri group condition on the application of cattle breeding, food crops, and cattle waste processing is done by t-test on each partial direct influence lane. The result of validation test of path coefficient on each path for direct effect can be seen in Table 2.

Table 2

Direct Test Result Testing

\begin{tabular}{clccc}
\hline No & \multicolumn{1}{c}{ Relation Between Variables } & $\begin{array}{c}\text { Path } \\
\text { Coefficient } \\
\text { (Bootstrapping) }\end{array}$ & t-statistics & Explanation \\
\hline 1 & $\begin{array}{l}\text { Farmers human resources quality (X1) à The } \\
\text { application of cattle breeding (X3) }\end{array}$ & 0.769 & 12.512 & Significant \\
$2 \quad \begin{array}{l}\text { Farmers human resources quality (X1) à The } \\
\text { application of food crops (X4) }\end{array}$ & 0.609 & 3.678 & Significant \\
$3 \quad \begin{array}{l}\text { Farmers human resources quality (X1) à The } \\
\text { application of cattle waste processing (X5) }\end{array}$ & 0.871 & 15.359 & Significant \\
$4 \quad \begin{array}{l}\text { Simantri group condition (X2) à The } \\
\text { application of the cattle breeding (X3) }\end{array}$ & 0.153 & 0.626 & Non Significant \\
$5 \quad \begin{array}{l}\text { Simantri group condition (X2) à The } \\
\text { application of food crops (X4) }\end{array}$ & $\begin{array}{l}\text { Simantri group condition (X2) à The } \\
\text { application of cattle waste processing (X5) }\end{array}$ & 0.090 & 0.571 & Non Significant \\
\hline
\end{tabular}

\subsubsection{Effect of Farmers Human Resources Quality on Simantri Application}

In accordance with the results of the validation test of the path coefficient on each path for the direct effects and effects in Table 2 above, the effect of the farmer's human resources quality on the application of cattle breeding, food crops, and cattle waste processing of respondents can be described as follows:

1. Farmers human resources quality (X1) had a significant and positive effect on the application of cattle breeding (X3). This result showed a positive value of 0.769 path coefficient with t-statistic equal to 12.512 (> 1.96). This result suggests that the better quality of farmers human resources of Simantri member will be able to improve the application of cattle breeding.

2. Farmers human resources quality (X1) had a significant and positive effect on the application of food crops (X4). This result showed a positive value of 0.609 path coefficient with $t$-statistic equal to 
3.678 (> 1.96). This result suggests that the better quality of farmers human resources of Simantri member, accordingly the application of food crops will be increased.

3. Farmers human resources quality (X1) had a significant and positive effect on the application of cattle waste processing (X5). This result showed a positive value of 0.871 path coefficient with tstatistic equal to 15.359 ( $>1.96)$. This result suggests that the better quality of farmers human resources of Simantri member, accordingly the application of cattle waste processing will be increased.

In accordance with the results of the research, the farmer's human resources quality (X1) has the greatest impact on the application of cattle waste processing (X5) compared to the application of cattle breeding (X3) and the application of food crops (X4). This is indicated by the value of pathway coefficient of influence $\mathrm{X} 1 \rightarrow \mathrm{X} 5$ of $0.871, \mathrm{X} 1 \rightarrow \mathrm{X} 3$, and X1 $\rightarrow$ X4 respectively of 0.769 and 0.609 . This result is reasonable, because most of the respondents do not have enough skills before joining Simantri program in processing cattle waste into solid and liquid fertilizer, whereas the skill of maintaining the cows and food crops have been mastered from generation to generation taught by their parents (informally) and supported by the experience of respondents who have more than ten years in both sectors. [11] states that skills are the result of the process of someone work experience about the method of a job because of its involvement in the execution of a job task. In extension agriculture, adoption can be interpreted as a process of behavior change either in the knowledge, attitude, and skills in a person after receiving "innovation" that conveyed by extension agent to the target [12].

Moreover, the addition of technological innovations introduced in the Simantri program is more applicable on the application of cattle waste processing (X5) compared to the application of cattle breeding (X3) and the application of food crops (X4). Therefore, it is necessary to improve the skills of farmers in processing the cattle waste into solid and liquid fertilizer through direct training and technical guidance. This skill enhancement is useful for obtaining compost, biogas, and biourine as fertilizer with good quality, effective and efficient.

\subsubsection{Effect of Simantri Group Condition on Simantri Application}

Referring to Table 2 above, the influence of Simantri group condition on the application of the cattle breeding, food crops, and cattle waste processing can be described as follows:

1. Simantri group condition (X2) had a positive effect but nonsignificant on the application of the cattle breeding (X3). This result showed a positive value of 0.153 path coefficient with t-statistic equal to $1.955(<1.96)$. Based on these results can be stated that whether good or bad the Simantri group conditions have no impact on the cattle breeding.

2. Simantri group condition (X2) had a positive effect but nonsignificant on the application of food crops (X4). This result showed a positive value of 0.090 path coefficient with t-statistic equal to $0.626(<1.96)$. Based on these results can be stated that conducive or not the condition of Simantri group does not affect the application of food crops.

3. Simantri group condition (X2) had a positive effect but nonsignificant on the application of cattle waste processing (X5). This result showed a positive value of 0.039 path coefficient with t-statistic equal to $0.571(<1.96)$. Based on these results it can be stated that the better of Simantri group condition does not have any impact on increasing the application of cattle waste processing. 
This result is quite logical considering the Simantri group condition (X2) consisting of residence distance (X21), local culture (X22), and social interaction (X23) as its reflected indicator is more giving positive support on the application of the cattle breeding (X3), on the application of food crops (X4), and on the application of cattle waste processing (X5) from the respondents. This result is in line with [13] which states that the requirement of adoption of innovation is not contradictory to existing culture pattern, the social structure of society and social institution, and social perception to innovation. Application (adoption) of technological innovation by farmers are influenced by internal and external factors. If the external factors of the respondents proved to have no effect on the level of application of technological innovations such as the results obtained in this research, then automatically the internal factors of the farmers who dominate the most dominant influence on the application of a technological innovation.

The distance of respondent's residence to the Simantri location and the cultivated land is no more than six kilometers. [14] said that the accessibility of livestock business location to the highway with \pm 1 $\mathrm{km}$ distance with diversity is less than $6 \mathrm{~km}$ is considered still conducive, thus facilitating the transportation of inputs and outputs of farming or livestock business. In general, local culture in Bali is very supportive of activities or business integration between food crops with cattle and cattle waste processing business into fertilizer.

[15] states that norms, customs, and other social governance arrangements play an important role in the agricultural production process. Furthermore, most of the respondents $(95.65 \%)$ have a very good social interaction with their fellow Simantri group members and with Simantri assistant officers. [16] says that with the social interaction among farmers there are will be an information exchange about farming knowledge and skills among them.

\section{Conclusion}

On average the Simantri Application level classified very high. When viewed from three types of main Simantri activities, it turns out the application level of cattle waste processing on average is classified as moderate. The farmer's human resources quality have proved has a positive and significant impact on the application of cattle breeding, food crops, and cattle waste processing. The Simantri group condition statistically has a positive but not significant effect on the application of cattle breeding, food crops, and cattle waste processing.

\section{Acknowledgments}

Our deep and sincere gratitude is given to God for giving us health and an opportunity to finish this writing. Thank you very much to our colleagues who have helped in the research and completed this writing. Special thanks to the chairman of Korpri Welfare Foundation of Bali Province, the Rector of Warmadewa University, the Dean of Agricultural Faculty of Warmadewa University, and also Head of Animal Husbandry Department of Warmadewa University.

\section{References}

[1] Ilham, et al. (2003). Development and Factors Affecting Wetland Conversion and Its Economic Impacts. IPB Press. Bogor.

[2] Utomo, R., Reksohadiprodjo, S., Widyobroto, B.P., Bachrudin, Z., \& Suhartanto, B. (1999). Synchronization of Energy Degradation and Protein in Rumen on Rice Basal Straw Rations to Improve the Efficiency of Cattle Nutrient Digestibility. Comprehensive Research Report HB V. Applied Science Projects and Applied Science Research. Gadjah Mada University, Yogyakarta. 
[3] Sudaratmaja, I.G.A.K. (2009). Integrated Agricultural Development Strategy. BPTP, Bali.

[4] Sariubang, M.A., Syam, A. \& Nurhayu, A. (2003). Livestock-Crops Farming System on Dryland in Takalar Regency, South of Sulawesi. BPTP South of Sulawesi.

[5] Suwandi. (2005). Sustainability of Integrated Farming System With Rice-Cattle Pattern in Sragen Regency: RAP-CLS Approach. Dissertation. Postgraduate Programme of Bogor Agricultural University, Bogor.

[6] Priyanti, A. (2007). Impact of Integrated Livestock and Crops System on Allocation of Working Time, Farmers Income and Expenditure. Dissertation. Postgraduate Programme of Bogor Agricultural University, Bogor.

[7] BPTP, Bali. (2011). Bali Province Adoption of Prima Tani Programme Becomes Simantri. Special Edition Penas XIII, June 21, 2011. Research and Development Department of BPTP, Bali.

[8] Mar'at. (1984). A Communication Concept. PT. Raja Grafindo Persada, Jakarta.

[9] Dajan, A. (1986). Introduction to Statistical Methods. Volume II. LP3ES, Jakarta.

[10] Singarimbun, M. \& Effendi, S. (2006). Survey Research Methods. Revised Edition LP3ES, Jakarta.

[11] Manulang. (1984). Personnel Management. Ghalia Indonesia, Jakarta.

[12] Mardikanto, T. (1993). Extension Agricultural Development. Sebelas Maret University Press, Surakarta.

[13] Suparlan, I.P. (1981). Human, Culture and Environment. CV. Rajawali, Jakarta.

[14] Ruswendi (2011). Final Report of Competitive Assessment, Acceleration of Adoption of Agricultural Waste Utilization Technology as Cattle Feed and Organic Fertilizer in Bengkulu. Balai BPTP, Bengkulu Province.

[15] Suradisastra, K. (2008). Farmer Empowerment Strategy Strategy. Agro Economic Research Forum. Indonesian Center for Agriculture Socio Economic and Policy Studies, Bogor.

[16] Walgito, B. (2011). Theories of Social Psychology. ANDI, Yogyakarta. 